\title{
OPTIMUM SAFETY LEVELS AND DESIGN RULES FOR THE ICELANDIC-TYPE BERM BREAKWATER
}

\author{
Sigurdur Sigurdarson ${ }^{1}$, Jentsje W. van der Meer ${ }^{2}$, Hans F. Burcharth ${ }^{3}$ and \\ John Dalsgaard Sørensen ${ }^{4}$,
}

This paper gives first an elaboration of berm recession equations for berm breakwaters and then new deterministic design rules for the Icelandic-type berm breakwater. Safety optimization calculations have been performed for a mild depth limited wave climate and for a situation at deep water. Repair strategies and possible failure with corresponding downtime have been taken into account, as well as actual market prices (in Iceland and Norway) for rock material and construction. Calculations show that low stability numbers for the largest rock armour layer give the optimal safety level.

\section{INTRODUCTION}

Guidance on selection of breakwater types and related design safety levels for breakwaters are almost non-existent, which is the reason that PIANC has initiated working group 47 on the subject "Criteria for the Selection of Breakwater Types and their Optimum Safety Level”. This paper presents ongoing work, particularly on the Icelandic-type berm breakwater, within the PIANC working group. It will concentrate on design guidance and on the optimum safety levels for this type of structure.

\section{THE ICELANDIC-TYPE BERM BREAKWATER}

Berm breakwaters have basically developed in two directions. The first type uses a few stone classes, which are constructed with an initially unstable berm and where this berm is allowed to reshape into a more gentle statically stable slope. On the other hand, there are more stable structures built of several stone classes, where only a few stones on the berm are allowed to move. These structures have been referred to as Icelandic-type berm breakwaters. The general method for designing an Icelandic-type berm breakwater is to tailormake the structure around the design wave load, possible quarry yield, available equipment, transport routes and required functions. Quarry yield prediction is presented as a tool in breakwater design.

\section{OPTIMUM SAFETY LEVELS}

In order to come to optimum safety levels for breakwaters a procedure has to be followed in numerical simulation for identification of minimum cost safety levels. Before such a numerical simulation can be performed, design rules should be available and also a description of the behaviour of the structure under (very) extreme wave conditions. The aforementioned procedure in

\footnotetext{
${ }^{1}$ Icelandic Maritime Administration, Iceland, sigurdur@sigling.is

${ }^{2}$ Van Der Meer Consulting B.V., The Netherlands, im@vandermeerconsulting.nl

${ }^{3}$ Aalborg University, Denmark, i5hfb@civil.auc.dk

${ }^{4}$ Aalborg University, Denmark, jds@civil.aau.dk
} 
numerical simulation (Burcharth and Sørensen, 2005 and 2006) gives amongst others the following items:

- Design of structure geometries by conventional deterministic methods corresponding to various chosen design wave heights;

- Definition of repair policy and related costs of repair;

- Definition of a model for damage accumulation and consequences of complete failure.

The above procedure has not yet been performed for the Icelandic-type berm breakwater and this paper is, as a part of the PIANC work, an attempt to fill in the gaps. The basic report for design of berm breakwaters at present is (PIANC WG 40, 2003).

\section{PROCEDURE FOR CALCULATIONS}

The objective is to identify the most economical safety levels over the lifetime of the structures. The procedure is to calculate the lifetime cost of a number of structures, which are deterministically designed to different safety levels and to identify the safety level corresponding to the lowest cost. The optimisation was performed with Monte Carlo simulations. The failure modes considered are the recession of the front of the berm and the rear side erosion (van der Meer and Veldman, 1992). Three limit states are considered:

- Serviceable limit state (SLS) corresponds to the limit of damage not affecting the function of the breakwater.

- $\quad$ Repairable limit state (RLS) corresponds to moderate damage.

- Ultimate limit state (ULS) corresponds to very severe damage.

\section{BERM RECESSION}

Most of the early tests on berm breakwaters were on breakwaters with a homogenous berm. Tørum (1998) collected data from different tests on homogenous berms from different laboratories. There was considerable scatter in the test results, both between different tests in the same series of tests from a specific laboratory and between tests from different laboratories. Tørum, 1998, presented a polynomial formula for the recession of the berm as a function of rock and hydraulic boundary conditions, $\mathrm{H}_{0} \mathrm{~T}_{\mathrm{o}}$. See Figure 1 for a definition of berm recession Rec.

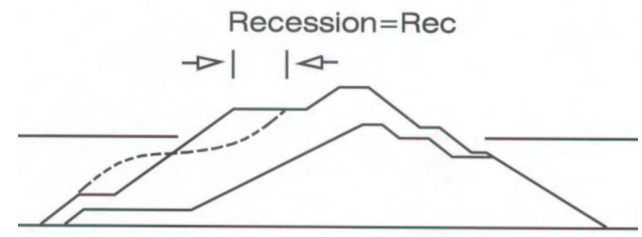

Figure 1. Recession of the berm on a berm breakwater 
Later Tørum modified the formula to include stone gradation and water depth, to a large extent based on test results for multilayer berm breakwaters, Tørum et al. 2003, PIANC WG 40, 2003. The latter PIANC formula is given by:

$$
\begin{aligned}
\operatorname{Rec} / \mathrm{D}_{\mathrm{n} 50}= & 0.0000027\left(\mathrm{H}_{\mathrm{o}} \mathrm{T}_{\mathrm{o}}\right)^{3}+0.000009\left(\mathrm{H}_{\mathrm{o}} \mathrm{T}_{\mathrm{o}}\right)^{2}+0.11 \mathrm{H}_{\mathrm{o}} \mathrm{T}_{\mathrm{o}}- \\
& \left(-9.9 \mathrm{f}_{\mathrm{g}}^{2}+23.9 \mathrm{f}_{\mathrm{g}}-10.5\right)-\mathrm{f}_{\mathrm{d}}
\end{aligned}
$$

with: $\quad f_{g}=D_{n 85} / D_{n 15}$ and $f_{d}=-0.16 d / D_{n 50}+4.0$

Without the correction terms of the stone gradation and water depth the formula goes through the origin. This means that only for zero wave height there will be no damage, but any wave larger than zero will give some recession. This is physically not correct. There will be a certain wave height below which no rock movement will occur. Actually the data which the formula is based on, Figure 2, (original Figure 12.1 in the PIANC-report), shows four test cases with $\mathrm{H}_{\mathrm{o}} \mathrm{T}_{\mathrm{o}}$ between 20 and 50 without any damage. The limiting wave condition should be in average somewhere between $\mathrm{H}_{\mathrm{o}} \mathrm{T}_{\mathrm{o}}=20-40$.

Furthermore, the influences of grading and water depth on berm recession are assumed to be rather small, certainly given the large overall scatter. Finally, a power function gives a much easier formula than a third order polynomial function. Taking $\mathrm{H}_{\mathrm{o}} \mathrm{T}_{\mathrm{o}}=20$ as the limiting value below which no berm recession occurs, the following expression can be derived which is quite close to the original formula of the PIANC-report (Figure 2):

$$
\mathrm{Rec} / \mathrm{D}_{\mathrm{n} 50}=0.037\left(\mathrm{H}_{\mathrm{o}} \mathrm{T}_{\mathrm{o}}-20\right)^{1.34}
$$

with $\quad \mathrm{Rec} / \mathrm{D}_{\mathrm{n} 50}=0$ for $\mathrm{H}_{\mathrm{o}} \mathrm{T}_{\mathrm{o}}<20$

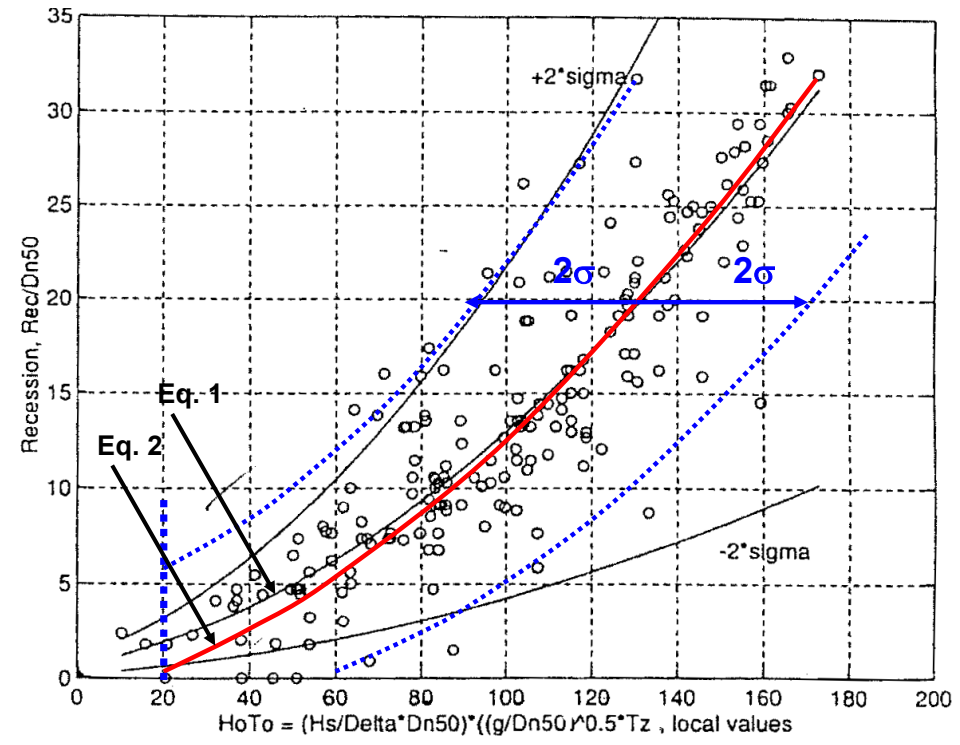

Figure 2. New fit of recession Rec versus $H_{0} T_{0}$ with new confidence intervals 
Another remark on the formula is the description of the scatter. The PIANCreport gives a scatter around the berm recession with a variation coefficient of 0.337 . With this variation coefficient the "2 sigma"-lines have been drawn in Figure 2. This way of describing the scatter may lead to a large over-prediction of scatter for $\mathrm{H}_{\mathrm{o}} \mathrm{T}_{\mathrm{o}}$-values larger than say 120 . In reality the scatter of the berm recession does not really increase with increasing $\mathrm{H}_{0} \mathrm{~T}_{0}$.

Figure 3 (original Figure 12.2 in the PIANC-report) shows that the maximum relative deviation from the mean value decreases considerably for $\mathrm{H}_{\mathrm{o}} \mathrm{T}_{\mathrm{o}}$-values larger than 100, where in fact it should be constant, according to the $+/$ - sigmalines. Therefore, another description of scatter should be found.

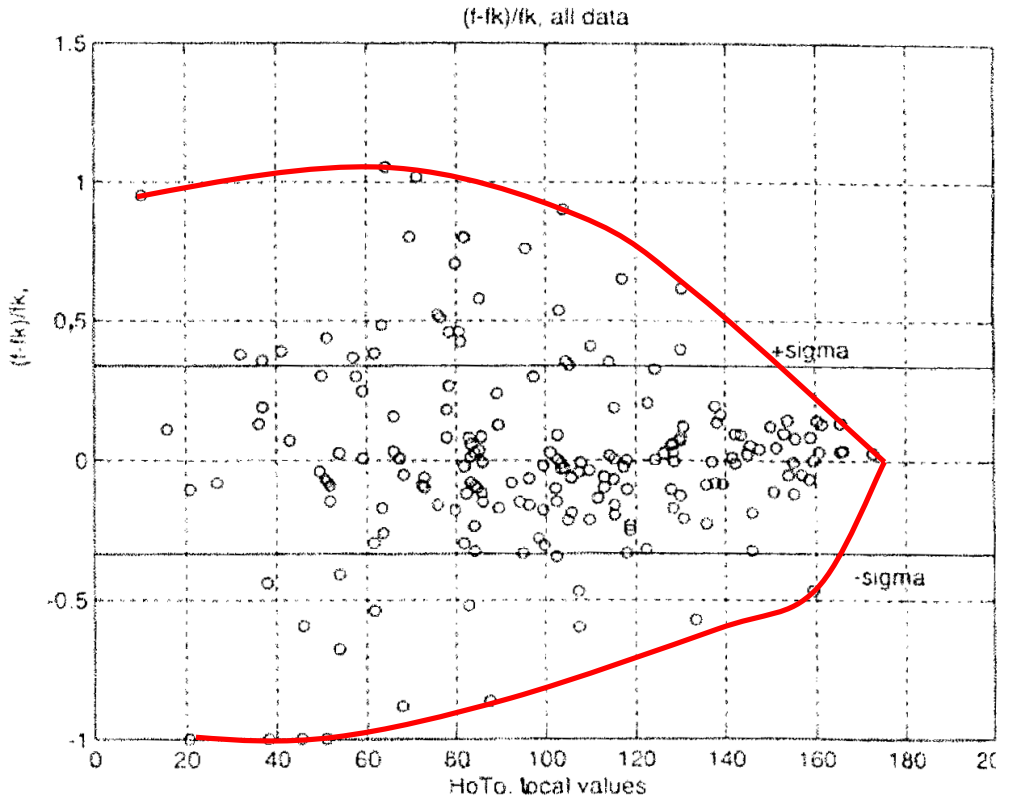

Figure 12.2. $\left(f-f_{k}\right) / f_{k}$ as a function of HoTo at the breakwater. Torum (1998)

Figure 3. Relative deviation from mean with lines for maximum deviation

A way to describe the scatter is to take the value 20 in equation 2 as a stochastic variable. Elaboration shows that the scatter can be described by Sc with a mean value of 20 and also with a standard deviation of $\sigma(\mathrm{Sc})=20$. The $2 \sigma$-lines have been given in Figure 1 and can be compared with the original lines. The right $2 \sigma$-line is now much better than the original one. Only the left line gives an over-prediction of recession for small $\mathrm{H}_{0} \mathrm{~T}_{0}$-values. But this is conservative. The main reason is that the limiting value of $\mathrm{H}_{0} \mathrm{~T}_{\mathrm{o}}=20$ is a little conservative and therefore also the scatter in this area is taken conservative.

The final equation for recession of the berm becomes: 


$$
\begin{array}{ll} 
& \operatorname{Rec} / \mathrm{D}_{\mathrm{n} 50}=0.037\left(\mathrm{H}_{\mathrm{o}} \mathrm{T}_{\mathrm{o}}-\mathrm{Sc}\right)^{1.34} \\
\text { with: } & \operatorname{Rec} / \mathrm{Dn} 50=0 \text { for } \mathrm{H}_{\mathrm{o}} \mathrm{T}_{\mathrm{o}}<\mathrm{Sc} \\
\text { with: } & \mu(\mathrm{Sc})=20 \text { and } \sigma(\mathrm{Sc})=20 .
\end{array}
$$

Equation 3 can be used to describe the behaviour of the berm of an Icelandictype breakwater under wave attack. It can also be compared with the recently constructed (and tested by nature) breakwater of Sirevåg, Norway, (Sigurdarson et al., 2003). Figure 4 shows the cross-section of this breakwater and Figure 5 gives test results with respect to berm recession. Equation 3 gives a little conservative estimate, which was already discussed above. The figure shows too that the fg-factor (influence of gradation) in the original formula 1 does not work well if it is applied outside its limitations.

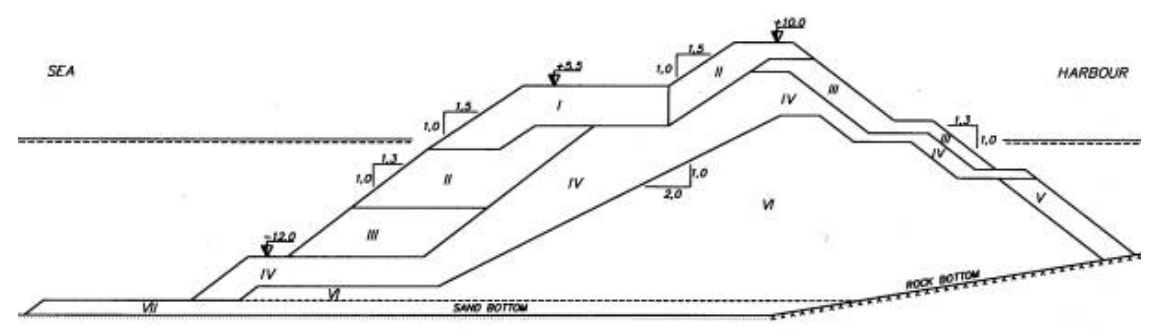

Figure 4. Cross-section of the Icelandic-type Sirevåg berm breakwater

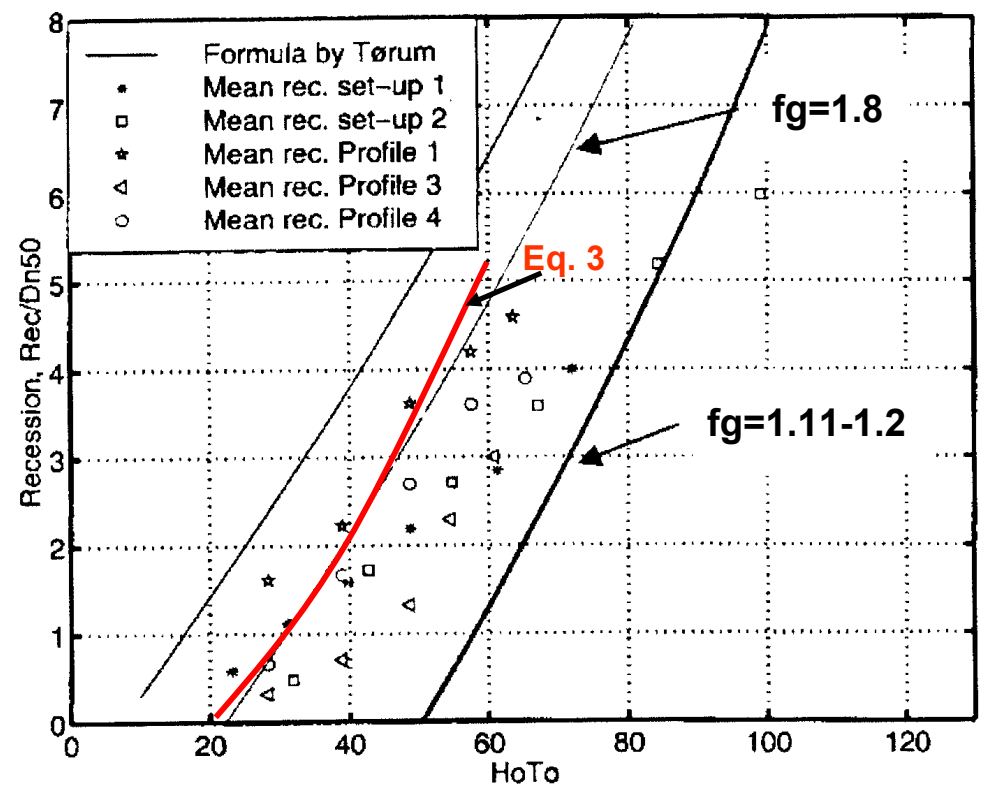

Figure 5. Recession of berm with equation (3) inserted in Figure 4.3 from (PIANC WG 40, 2003). 


\section{CONCEPTUAL DESIGN RULES}

The design of an Icelandic-type berm breakwater does not really depend on a formula for the recession of the berm. The main idea is that the biggest rocks from a quarry are kept apart to make the upper two layers of the berm and a part of the down slope. From the total quarry output this will only be a few percent. This large and most important layer should be constructed with care. Rocks should be placed one by one to achieve high interlocking without loosing the porosity. The Sirevåg and Keilisnes berm breakwater in Norway and Iceland respectively have been chosen here as representative to develop deterministic design rules. In summary:

- The upper layer of the berm consists of two layers of rock and extents on the down slope at least to mean sea level;

- The rock size of this layer is determined by: $\mathrm{H}_{\mathrm{s}} / \Delta \mathrm{D}_{\mathrm{n} 50}=2.0$. Larger rock may be used too;

- $\quad$ Slopes below and above the berm are 1:1.5;

- The berm width is $3.5^{*} \mathrm{H}_{\mathrm{s}}$;

- The berm level is $0.65^{*} \mathrm{H}_{\mathrm{s}}$ above design water level;

- The crest height is given by $\mathrm{R}_{\mathrm{c}} / \mathrm{H}_{\mathrm{s}}{ }^{*} \mathrm{~s}_{\mathrm{op}}{ }^{1 / 3}=0.35$.

\section{REPAIR STRATEGY AND DESIGN LIMIT STATES}

The recession, Rec, is calculated for each storm with $\mathrm{H}_{\mathrm{o}} \mathrm{T}_{\mathrm{o}}>\mathrm{Sc}$

If in storm $n+1 \operatorname{Rec}^{\mathrm{n}+1}>\operatorname{Rec}^{\mathrm{n}}$ then $\operatorname{Rec}^{\mathrm{n}+1}$ is used, otherwise $\operatorname{Rec}^{\mathrm{n}+1}$ is disregarded.

\section{Serviceable limit state (SLS)}

Repair takes place when total recession in storm $\mathrm{n}$ is larger than half of the initial berm width, i.e. Rec $\geq 1.75^{*} \mathrm{H}_{\mathrm{s}}^{\mathrm{y}}$. Eroded volume of berm is taken as $\mathrm{V}_{\mathrm{r}}^{\mathrm{b}}=\mathrm{Rec}^{*} \mathrm{H}_{\mathrm{s}}^{\mathrm{y}}$ and the related $\operatorname{cost} \mathrm{C}_{\mathrm{r}}^{\mathrm{b}}=1.5 * \mathrm{U}_{\mathrm{cl}} * \mathrm{~V}_{\mathrm{r}}$

\section{Repairable limit state (RLS)}

Repair takes place if the rear side and the crest are eroded in a storm, i.e. when for unchanged $\mathrm{s}_{\mathrm{op}}$,

$$
1.44 \mathrm{H}_{\mathrm{s}}^{\mathrm{y}} \leq \mathrm{H}_{\mathrm{s}} \leq 2.12 \mathrm{H}_{\mathrm{s}}^{\mathrm{y}}
$$

The upper and lower limits in Eq. 4 are the same as presented by van der Meer and Veldman (1992) for stability of the rear of a berm breakwater, where the lower limit corresponds to $\mathrm{R}_{\mathrm{c}} / \mathrm{H}_{\mathrm{s}}{ }^{*} \mathrm{~s}_{\mathrm{op}}{ }^{1 / 3}=0.25$ which stands for start of damage and the upper limit corresponds to 0.17 which stands for severe damage.

Eroded plus extra added volume is taken as $\mathrm{V}_{\mathrm{r}}^{\mathrm{c}}=8 * \mathrm{H}_{\mathrm{s}}^{\mathrm{y}} * \mathrm{D}_{1}$ and the related cost $\mathrm{C}_{\mathrm{r}}^{\mathrm{c}}=1.5 * \mathrm{U}_{\mathrm{cl}} * \mathrm{~V}_{\mathrm{r}}^{\mathrm{c}}$

\section{Ultimate limit stat (ULS)}

Failure occurs if

$$
\operatorname{Rec}^{\mathrm{n}+1} \geq 3.5 \mathrm{H}_{\mathrm{s}}^{\mathrm{y}}-\sum_{1}^{n} \operatorname{Rec}
$$


or

$$
\mathrm{H}_{\mathrm{s}}>2.12 \mathrm{H}_{\mathrm{s}}^{\mathrm{y}} \text { (for unchanged } \mathrm{S}_{\mathrm{op}} \text { ) }
$$

In both cases the volume to replace is taken as $\mathrm{V}_{\mathrm{f}}=\mathrm{V}_{1}+0.8^{*} \mathrm{~V}_{2}$, that is the total volume of class 1 and $80 \%$ of class 2 . The related cost is taken as $\mathrm{C}_{\mathrm{f}}=$ $2.5 * \mathrm{C}_{\mathrm{c} 1} * \mathrm{~V}_{\mathrm{f}}$.

Downtime cost occurs only in case of failure.

\section{WAVES}

Various wave climates were considered in PIANC, 1991, for conventional rubble mound breakwaters. From that report is the shallow water wave climate with depth-limited wave attack. The deep water wave climate where wave heights continue to increase with increasing return period is from the Baltic Sea. For the shallow water case with water depth of $11 \mathrm{~m}$ at the toe of the structure, depth-limited waves from Follonica were used, see Table 1. For the deep water case with a water depth of $20 \mathrm{~m}$ at the toe of the structure, Baltic Sea waves were used. The two wave types were scaled to give equal wave height for the 50 year return period.

Table 1. The wave statistics for the depth limited and deep water waves.

\begin{tabular}{ccc} 
Return period & $\begin{array}{c}\text { Follonica waves } \\
\text { Depth limited, } \mathrm{h}=11 \mathrm{~m} \\
\mathrm{H}_{\mathrm{s}}(\mathrm{m})\end{array}$ & $\begin{array}{c}\text { Baltic Sea waves } \\
\text { Deep water, } \mathrm{h}=20 \mathrm{~m}\end{array}$ \\
\hline 5 & 4.35 & $\mathrm{H}_{\mathrm{s}}(\mathrm{m})$ \\
25 & 5.07 & 3.55 \\
50 & 5.36 & 4.71 \\
100 & 5.64 & 5.36 \\
200 & 5.92 & 6.08 \\
400 & 6.2 & 6.88 \\
1000 & 6.56 & 7.75 \\
\hline
\end{tabular}

\section{BUILT-IN PRICES FOR ROCK}

The built-in prices for rock used for the simulations were derived from two datasets of bids for actual projects. In both projects the design was adjusted to an armourstone quarry yield prediction and the contractors could read from geological reports included in the bidding documents that there would not be any or only marginal leftovers in the quarry when the project was finished. All prices are in EUR per $\mathrm{m}^{3}$ of material, rock or core material, placed in breakwater including voids. The two data sets described below are shown in Table 2.

1. Mean value of 6 bids for the Sirevåg, Norway, berm breakwater in 1998 . The bids range from $70-112 \%$ of the mean value of the bids. The Engineer did not make a cost estimate. Three dedicated armourstone quarries were used for the project, all less than $1 \mathrm{~km}$ from the construction site. Due to narrow roads with limited bearing capacity all material from the largest 
quarry had to be sailed to the project site. The prices are regulated to June 2007.

2. Mean value of 5 bids for a new berm breakwater in Thorlakshofn, Iceland, in 2003. The bids range from $90-104 \%$ of the Engineers cost estimate. The dedicated armourstone quarry for the project is located about $2 \mathrm{~km}$ from the construction site. As there was a direct access from the quarry to the construction site without entering the town it was possible to use mining trucks for the transport. The prices are regulated to June 2007.

Figure 6 shows the built-in unit prices as a function of weight of the rock as well as a trend line through the Sirevåg data. It was decided to use only the Sirevåg data for this study.

Table 2. Built-in unit prices for rock from biddings on two actual projects.

\begin{tabular}{|c|c|c|c|}
\hline \multicolumn{2}{|c|}{ Sirevåg } & \multicolumn{2}{|c|}{ Thorlakshofn } \\
\hline Mean mass $(\mathrm{t})$ & $\mathrm{EUR} / \mathrm{m}^{3}$ & Mean mass $(\mathrm{t})$ & EUR/m $m^{3}$ \\
\hline 0.1 & 10.1 & 0.1 & 11.1 \\
\hline 0.6 & 14.7 & 0.53 & 13.4 \\
\hline 2 & 15.0 & 1.7 & 14.5 \\
\hline 6 & 18.9 & 4.7 & 16.4 \\
\hline 13.3 & 23.5 & 13.7 & 17.9 \\
\hline 23.3 & 27.0 & & \\
\hline
\end{tabular}

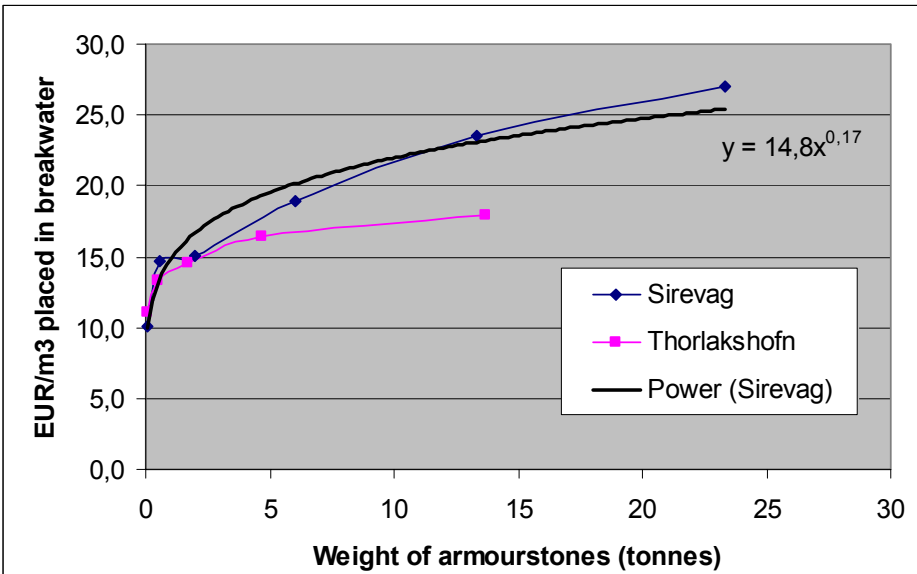

Figure 6. Built-in unit prices for rock as a function of weight

The built-in unit prices for repairs are higher than normal construction prices. The repair mainly needs large stones and less of the smaller stone classes as well as the quarry run. The mobilization cost is also higher. The repair unit prices for the Serviceability limit state (SLS) and the Repairable limit state (RLS) are taken as 1.5 times the initial unit prices. The unit prices for repair of failure, the Ultimate limit state (ULS), are higher and are taken as 2.5 times the initial unit prices. 


\section{CASE STUDIES}

\section{Input data}

Two cases are considered, a shallow water case with $11 \mathrm{~m}$ water depth exposed to the Follonica waves and a deep water case with $20 \mathrm{~m}$ water depth exposed to the Baltic Sea waves, Table 1. The breakwaters are designed deterministically for the following data:

- Reduced buoyant density of the armour layer: $\Delta=1.63$ corresponding to $\rho_{\mathrm{s}}=2.70 \mathrm{t} / \mathrm{m}^{3}$ and $\rho_{\mathrm{w}}=1.025 \mathrm{t} / \mathrm{m}^{3}$;

- Design return periods: $\mathrm{y}=5,25,50,100,200,400$ and 1000 years;

- $\quad$ Stability number of stone class $\mathrm{I}: \mathrm{H}_{\mathrm{o}}{ }^{\text {design }}=1.8,2.0,2.4,2.8$ and 3.2;

- Wave steepness $\mathrm{s}_{\mathrm{op}}=0.035$;

- $\mathrm{D}_{\mathrm{n} 50}$ of stone class II $=0.8 * \mathrm{D}_{\mathrm{n} 50}$ of stone class I;

- Downtime cost $=18,000 \mathrm{EURO} / \mathrm{m}$ breakwater for $1 \mathrm{~km}$ breakwater;

- Interest rate 5\% p.a. (inflation included);

- Structure service life time 50 years.

\section{Results of shallow water case}

The results of the cost optimization simulations for the shallow water case are shown in Figure 7. The total cost as a function of the design return period is given for various design stability numbers.

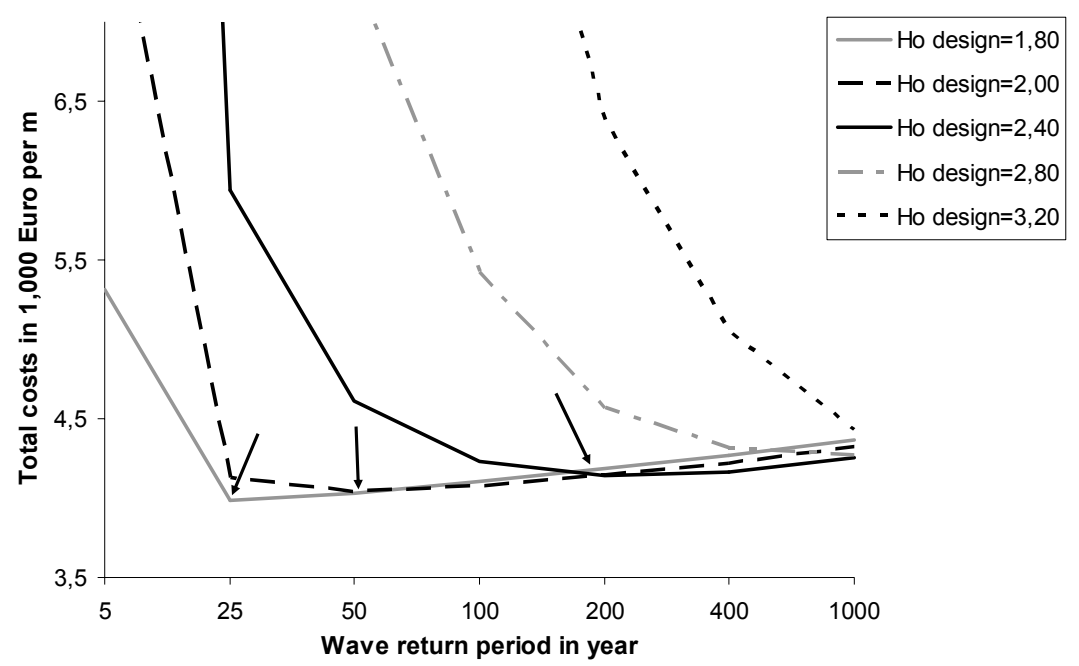

Figure 7. Shallow water case, total cost as a function of design return period for various design stability numbers. The arrows point to the minimum values.

The optimum safety level has a flat minimum towards higher return periods, but rather steep increase in cost towards the lower return periods. Design for a low stability number is more economical than to design for a high stability number. The most economical design corresponds to $\mathrm{H}_{\mathrm{o}}^{\text {design }}=1.8$ and a design return period of 25 years. But as the minimum is very flat, there is only $3 \%$ increase in total cost if designed for 100 years return period instead of 25 years. For the 
stability number of $\mathrm{H}_{\mathrm{o}}^{\text {design }}=2.0$ the design return period of 50 years is the most economical, but there is only a 3\% increase in total cost if designed for 200 years return period. Table 3 shows the split up of the total cost for the design stability number $\mathrm{H}_{\mathrm{o}}^{\text {design }}=2.0$. It can be seen that there is a slight increase in construction cost when designing for higher return period. The repair cost increases towards lower return periods, but the largest changes in cost occur for the cost of failures for low return periods.

Table 3. Split up of total cost for shallow water case designed for $\mathbf{H}_{\mathrm{o}}=\mathbf{2 . 0}$

\begin{tabular}{rrrrrr}
\hline $\begin{array}{c}\text { Return period } \\
\text { (years) }\end{array}$ & $\begin{array}{c}\text { Weight class I Construction cost } \\
\text { (tonnes) }\end{array}$ & $\begin{array}{r}\text { Repair cost } \\
\text { (EUR) }\end{array}$ & $\begin{array}{c}\text { Cost of } \\
\text { (EUR) }\end{array}$ & $\begin{array}{c}\text { Total cost } \\
\text { failures (EUR) }\end{array}$ \\
\hline 5 & 6 & 3666 & 223 & 4225 & 8114 \\
25 & 10 & 3888 & 54 & 187 & 4128 \\
50 & 12 & 3975 & 27 & 33 & 4035 \\
100 & 14 & 4059 & 10 & 1 & 4071 \\
200 & 16 & 4141 & 3 & 1 & 4144 \\
400 & 19 & 4220 & 0 & 0 & 4220 \\
1000 & 22 & 4321 & 0 & 0 & 4321 \\
\hline
\end{tabular}

\section{Results of deep water case}

The results for the deep water case are given in Figure 8. This graph shows the same characteristics as for the shallow water case with flat minimum towards the higher stability numbers and steep increase towards the lower stability numbers. The most economical design corresponds to $\mathrm{H}_{\mathrm{o}}^{\text {design }}=1.8$ for 100 years return period and $\mathrm{H}_{\mathrm{o}}^{\text {design }}=2.0$ for 200 years return period.

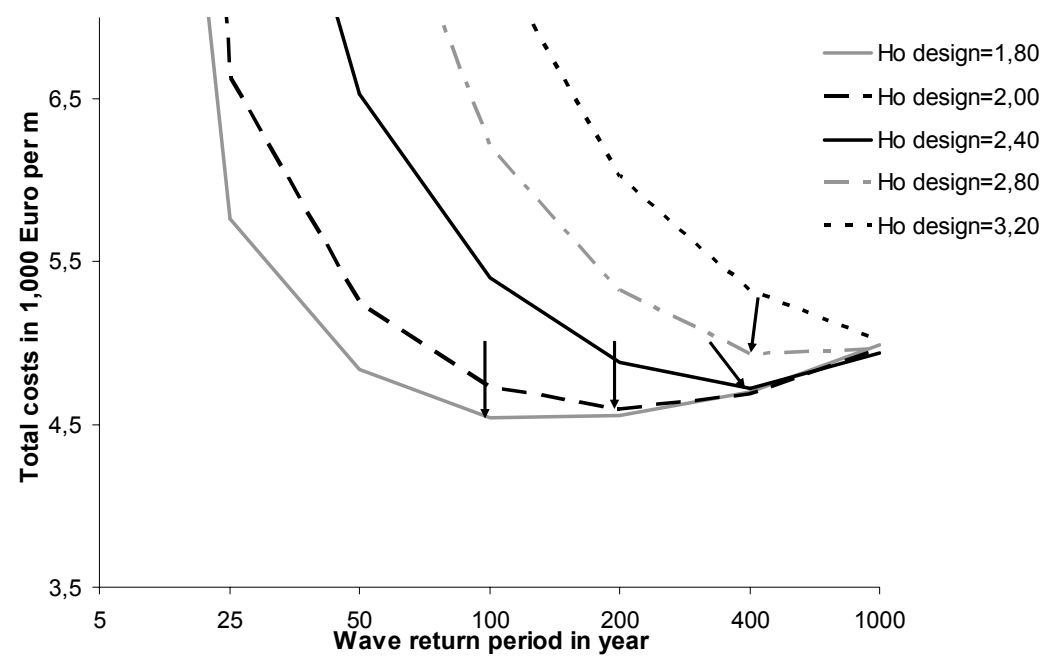

Figure 8. Deep water case, total cost as a function of design return period for various design stability numbers. The arrows point to the minimum values. 
A comparison of Figures 7 and 8 indicates that the shallow water case is less expensive than the deep water case, which can be explained by the higher probability of extreme wave heights in the deep water case. The optimum safety level is reached for lower return period for the shallow water case than for the deep water case. But the assumption has to be noticed, that in the calculations all rock sizes are available. For the shallow water case with 50 years return period the stability number of 2.0 corresponds to a mean weight of class I stones of 12 tonnes, while for the deep water case with 200 years return period the stability number of 2.0 corresponds to a mean weight of class I stones of 25 tonnes.

\section{COMPARISON WITH THE DESIGN OF RECENTLY CONSTRUCTED ICELANDIC-TYPE BERM BREAKWATERS}

Table 4 lists some recent berm breakwater projects in Iceland and Norway (Sigurdarson et al. 2006). In all cases the breakwaters have been designed for a wave height with 100 years return period. In four out of six cases the stability number of the largest stone class has been close to 2.0, or in the range $\mathrm{H}_{\mathrm{o}}=1.9$ to 2.2 .

Table 4. List of recently constructed Icelandic-type berm breakwaters.

\begin{tabular}{cccccc}
\hline $\begin{array}{c}\text { Breakwater } \\
\text { project }\end{array}$ & $\begin{array}{c}\text { Design return } \\
\text { period }(\mathrm{y})\end{array}$ & $\begin{array}{c}\text { Design wave } \\
\mathrm{H}_{\mathrm{s}}(\mathrm{m})\end{array}$ & $\begin{array}{c}\text { Design water } \\
\text { depth }(\mathrm{m})\end{array}$ & $\begin{array}{c}\text { Class I } \\
\text { (tonnes) }\end{array}$ & $\begin{array}{c}\text { Design } \\
\mathrm{H}_{\mathrm{o}}\end{array}$ \\
\hline Sirevåg & 100 & 7.0 & 19 & $20-30$ & 2.1 \\
Húsavík & 100 & 6.8 & 13 & $16-30$ & 1.9 \\
Grindavík* & 100 & 5.1 & 10 & $15-30$ & 2.0 \\
Hammerfest & 100 & 7.5 & 25 & $20-35$ & 2.2 \\
Thorlákshöfn & 100 & 5.7 & 9 & $8-25$ & 1.9 \\
\hline
\end{tabular}

* Class I stones on the Grindavik breakwaters are only used on a limited part of the breakwater heads. The data here corresponds to class II stones used on the most exposed trunk section.

It is important to be aware of that the design return period and the stability number are dependent variables. From Table 1 it can be concluded that for the depth limited case the wave height with 100 years return period is about $5 \%$ higher than for 50 years return period and about 11\% higher than for 25 year return period. If the Sirevåg berm breakwater had been designed for waves with 50 or 25 years return periods instead of 100 years, but with unchanged stone classes, the stability number of the largest stone class would be 2.0 and 1.9 respectively. That is very close to the optimum safety level for the shallow water case with $\mathrm{H}_{\mathrm{o}}{ }^{\text {design }}=1.8$ and design return period of 25 years. For the Hammerfest case, on the other hand, which is a more deep water case it was difficult to come closer to the optimum safety level of $\mathrm{H}_{\mathrm{o}}$ design $=1.8$ for 100 years return period as that would have needed a stone class with a mean weight of 46 tonnes instead of the 25 tonnes that were used. However, the simulations are not valid for such a case because the unit price for such big rocks is underestimated in the simulations. 
It can be concluded that the design of these recent breakwaters follows the general recommendation of this paper. With the required stone sizes available it has been possible to design the berm breakwaters with low stability numbers close to the optimum safety levels.

\section{CONCLUSIONS}

As a consequence of the rather flat minimum of the optimum safety levels it is preferable to choose a rather conservative design. The same conclusion was reached by Burcharth and Sørensen (2006) for conventional rubble mound breakwaters. This means the Icelandic-type berm breakwater should be designed for a low stability number, if possible $\mathrm{H}_{\mathrm{o}}<2.0$. Optimum safety levels correspond to $\mathrm{H}_{\mathrm{o}}$ of 1.8 and 2.0 and return periods of 25 and 50 years. With only $2 \%$ additional cost design for 100 years return period practically avoids repair.

The conclusion that it is more economical to design for low stability numbers and high return periods presumes that a good quarry, having all required stone sizes should be available. When using natural rock in design the natural limitation of rock sizes should be taken into account. Sigurdarson et al. 2003, 2005 and 2006 have shown how quarry yield prediction is used as an integrated part of the design process.

\section{REFERENCES}

Burcharth, H. F. and J.D. Sørensen, 2005. Optimum safety levels for breakwaters. Proc. Coastlines Structures and Breakwaters 2005, ICE. 483-495.

Burcharth, H.F., J.D. Sørensen, 2006. On optimum safety levels of breakwaters. PIANC congress 1996

PIANC WG12, 1991. Analysis of rubble mound breakwaters. PIANC.

PIANC WG40, 2003. State-of-the-Art of Designing and Constructing Berm Breakwaters. PIANC.

Sigurdarson, S., A. Jacobsen, O.B. Smarason, S. Bjørdal, G. Viggosson, C. Urrang, A. Tørum, 2003. Sirevåg Berm Breakwater, design, construction and experience after design storm. Proc. Coastal Structures 2004, ASCE, 1212-1224.

Sigurdarson, S., A. Loftsson, A.E. Lothe, E. Bjertness, O.B. Smarason, 2005. Berm Breakwater Protection for the Hammerfest LNG Plant in Norway - Design and Construction. Proc. Coastlines, Structures and Breakwaters 2005, ICE. 349-362.

Sigurdarson, S., Smarason, O.B., Viggosson, G. and Bjørdal, S., 2006. Wave height limits for the statically stable Icelandic-type Berm Breakwater, Proc. ICCE 2006, ASCE, 5046-5058.

Tørum, A., 1998. On the stability of berm breakwaters in shallow and deep water. Proc. $26^{\text {th }}$ Int. Conf. Coastal Eng., ASCE, 1435-1448.

Tørum, A., F. Kuhnen, A. Menze, 2003. On berm breakwaters. Stability, scour, overtopping. Coastal Eng. 49: 209-238.

Van der Meer, J.W., J.J. Veldman, 1992. Singular points at berm breakwaters: scale effects, rear, roundhead and longshore transport. Journal of Coastal Engineering, 17. 153-171. 
KEY WORDS - CSt07

Abstract acceptance number: 60 .

Paper title: OPTIMUM SAFETY LEVELS AND DESIGN RULES FOR THE ICELANDIC-TYPE BERM BREAKWATER

Authors: $\quad$ Sigurdur Sigurdarson, Jentsje W. van der Meer, Hans F. Burcharth and John Dalsgaard Sørensen,

Keywords: Safety levels or optimum safety levels

Breakwater

Berm breakwater

Built-in prices

Lifetime cost 